Archive for

Organic Chemistry

Arkivoc 2017, part iii, $140-150$

\title{
Lewis acid-catalyzed Wolff cyclocondensation in the synthesis of (1H-1,2,3-triazolyl)furoxans
}

\author{
Leonid L. Fershtat, ${ }^{* a}$ Maxim R. Radzhabov, ${ }^{\mathrm{a}, \mathrm{b}}$ Anna A. Romanova, ${ }^{\mathrm{b}, \mathrm{c}}$ Ivan V. Ananyev, ${ }^{\mathrm{c}}$ \\ and Nina N. Makhova*a
}

${ }^{a}$ N. D. Zelinsky Institute of Organic Chemistry, Russian Academy of Sciences, 47, Leninsky prosp., 119991 Moscow, Russian Federation

${ }^{b}$ Higher Chemical College, Russian Academy of Sciences, 125047 Moscow, Russian Federation

${ }^{c}$ A. N. Nesmeyanov Institute of Organoelement Compounds, Russian Academy of Sciences, 28 Vavilova str., 119991 Moscow, Russian Federation

Emails: fershtat@ioc.ac.ru, mnn@ioc.ac.ru

\section{Dedicated to Prof. Oleg A. Rakitin on the occasion of his 65th birthday}

Received 02-22-2017

Accepted 03-13-2017

Published on line 05-21-2017

\section{Abstract}

Novel regioselective approach to the synthesis of (1H-1,2,3-triazol-1-yl)furoxans based on Lewis acid-catalyzed Wolff cyclocondensation of aminofuroxans with diazo- $\beta$-dicarbonyl compounds has been developed. This approach allows to involve aminofuroxans as substrates which are very weak nucleophiles and usually do not participate in reactions with common electrophiles.

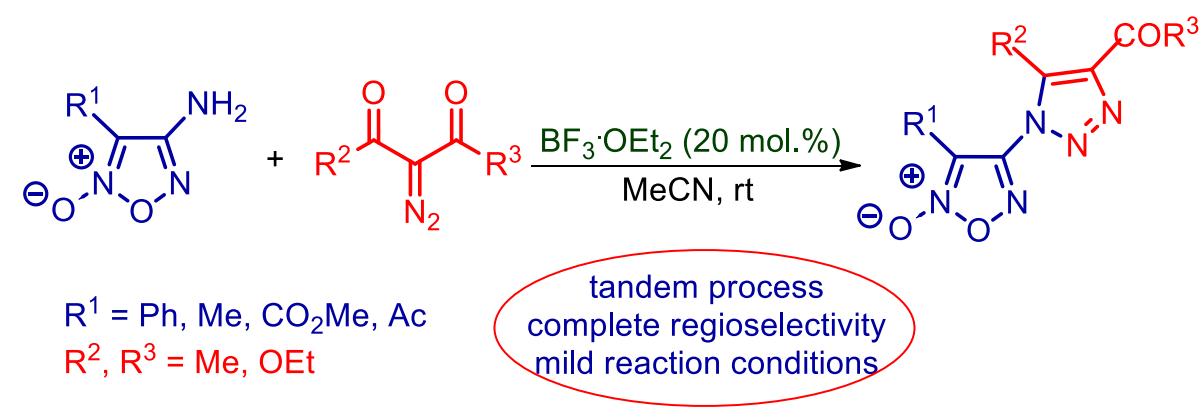

Keywords: Furoxan, oxadiazole, triazole, Lewis acid, Wolff cyclocondensation, nitrogen heterocycles 


\section{Introduction}

One of the useful tools for the design of new drug candidates with improved pharmacokinetic profiles is the molecular hybridization of different compounds with known pharmacological activity. ${ }^{1,2}$ To solve this issue, it is necessary to create new, highly effective and regioselective methods. Recent scientific investigations of our laboratory were directed towards the synthesis and reactivity of nitrogen-oxygen containing heterocycles 1,2,5-oxadiazole 2-oxides (furoxans). ${ }^{3,4}$ Furoxans are unique representatives of heterocyclic compounds. On the one hand they are of interest as high energy compounds due to a positive enthalpy of formation and the presence of two active oxygen atoms in the molecule. ${ }^{5-12}$ On the other hand furoxan derivatives reveal a wide spectrum of pharmacological activity owing to their ability to release NO under physiological conditions. ${ }^{13-19}$ Our last developments resulted in new, effective one-pot approaches for the synthesis of a series of hybrid heterocyclic systems incorporating furoxan ring connected with various pharmacophoric and/or energy rich poly-nitrogen (nitrogen-oxygen) heterocycles (isomeric 1,2,3- and 1,2,4-triazoles, 1,2,4- and 1,3,4-oxadiazoles, tetrazole, pyridines, tetrahydroisoquinoline, indenopyridine, etc.). ${ }^{20-28}$

Among synthesized compounds (1,2,3-triazol-1-yl)furoxan derivatives 1 attract special attention due to a wide variety of their pharmacological activity. The 1,2,3-triazole nucleus is found in a large number of compounds with agrochemical and pharmaceutical uses, ${ }^{29}$ shows anti-HIV, ${ }^{30}$ antimicrobial, ${ }^{31}$ antibacterial, ${ }^{32}$ and antitumor ${ }^{33}$ properties and has also found many applications in chemical industries. ${ }^{34}$ Cycloadditions of azides to alkynes and their derivatives (Huisgen reaction) ${ }^{34-36}$ continue to be the main synthetic route to 1,2,3triazoles. The reactions are usually catalyzed with transition metals and carried out at room or elevated temperature. Reactivity and regioselectivity in reactions of acetylenes with azides depends strongly on electronic and steric factors of both reagents.

Earlier $^{22}$ we attempted to synthesize (1,2,3-triazol-1-yl)furoxans 1 based on the [3+2] cycloaddition of azidofuroxans with acetylene derivatives. Unfortunately, in contrast to analogous reactions of other heterocyclic azides (in particular, azidofurazans ${ }^{37,38}$ ), the expected cycloaddition products were not obtained in any of the organic solvents even at prolonged heating. The [3+2] cycloaddition of azidofuroxans to internal and terminal acetylenes was found to occur only in the ionic liquids medium at prolonged heating and resulted in (1H-1,2,3-triazol-1-yl)furoxans in moderate to good yields. The reaction with terminal acetylenes proceeded with high regioselectivity, but another regioisomer was also formed in significant amounts. A decreased reactivity of azidofuroxans in [3+2] cycloaddition reaction connected, evidently, with a strong electronwithdrawing character of the furoxan ring. ${ }^{39}$ Therefore, it was of interest to develop a new, more effective and regioselective method for the synthesis of (1H-1,2,3-triazol-1-yl)furoxans 1 .

We paid attention to 1,2,3-triazole synthesis based on Wolff's cyclocondensation of diazoketones with aromatic and aliphatic amines under different catalysts. This reaction was discovered in $1902^{40,41}$ and has become one of the known synthetic approaches to 1,2,3-triazoles. ${ }^{42,43}$ The advantage of this method is that it yields only one of the two possible regioisomers of the 1,2,3-triazoles with unsymmetrically substituted substrates and safe amines are used instead of dangerous azido derivatives. Since aminofuroxans are rather available compounds, ${ }^{3}$ we aimed to develop new, regioselective method for the synthesis of $(1 \mathrm{H}-1,2,3$-triazol1 -yl)furoxans 1 by an interaction of 4 -aminofuroxans 2 with diazo- $\beta$-dicarbonyl compounds $\mathbf{3}$.

\section{Results and Discussion}

The investigations were begun with screening of the optimal conditions for the reaction of aminofuroxan $2 a$ with 3-diazo-2,4-dioxopentane (3a) (Table 1). Different Lewis acids as catalysts, their amount, temperature, 
solvent and reactants ratio were varied. As expected, in absence of any catalyst the reaction did not occur (Table 1, entry 1). With the use of 10 mol.\% of $\mathrm{BF}_{3} \cdot \mathrm{OEt}_{2}$ target (1,2,3-triazolyl)furoxan 1a was isolated in moderate yield (entry 2). The increase of catalyst amount to 20 mol.\% significantly increased the yield to $83 \%$ (entry 3), while further increase of catalyst molar equivalents resulted in yield decrease (entries 4,5). Probably, 10 mol.\% of $\mathrm{BF}_{3} \cdot \mathrm{OEt}_{2}$ is insufficient, while the increase in amount of catalyst more than 20 mol.\% partially blocks the amino group of furoxan 2 a. Utilization of transition metal salts afforded target product only in trace amounts (entries 6-9). Replacement of MeCN with DMF or [bmim]BF 4 as well as variation of temperature and reactants ratio also did not improve the product's yield (entries 10-15). Iron (III) chloride and nickel nitrate were also ineffective in this reaction (entries 16,17). Therefore, the optimal conditions were found to include reactants ratio $1: 1$ and $20 \mathrm{~mol}^{\circ} \% \mathrm{BF}_{3} \cdot \mathrm{OEt}_{2}$ as catalyst in $\mathrm{MeCN}$ at room temperature.

Table 1. Optimization of the reaction conditions

\begin{tabular}{|c|c|c|c|c|c|}
\hline Entry & Catalyst (mol. \%) & Solvent & Equiv. of $\mathbf{3 a}$ & $\mathrm{T},{ }^{\circ} \mathrm{C}$ & Yield, $\%^{a}$ \\
\hline 1 & - & $\mathrm{MeCN}$ & 1.0 & 20 & - \\
\hline 2 & $\mathrm{BF}_{3} \cdot \mathrm{OEt}_{2}(10)$ & $\mathrm{MeCN}$ & 1.0 & 20 & 30 \\
\hline 3 & $\mathrm{BF}_{3} \cdot \mathrm{OEt}_{2}(20)$ & $\mathrm{MeCN}$ & 1.0 & 20 & 83 \\
\hline 4 & $\mathrm{BF}_{3} \cdot \mathrm{OEt}_{2}(50)$ & $\mathrm{MeCN}$ & 1.0 & 20 & 30 \\
\hline 5 & $\mathrm{BF}_{3} \cdot \mathrm{OEt}_{2}(100)$ & $\mathrm{MeCN}$ & 1.0 & 20 & 58 \\
\hline 6 & $\mathrm{GaCl}_{3}(10)$ & $\mathrm{MeCN}$ & 1.0 & 20 & Trace $^{b}$ \\
\hline 7 & $\mathrm{Sc}(\mathrm{OTf})_{3}(10)$ & $\mathrm{MeCN}$ & 1.0 & 20 & Trace $^{b}$ \\
\hline 8 & $\mathrm{Y}(\mathrm{OTf})_{3}(10)$ & $\mathrm{MeCN}$ & 1.0 & 20 & Trace $^{b}$ \\
\hline 9 & $\mathrm{Yb}(\mathrm{OTf})_{3}(10)$ & $\mathrm{MeCN}$ & 1.0 & 20 & Trace $^{b}$ \\
\hline 10 & $\mathrm{BF}_{3} \cdot \mathrm{OEt}_{2}(20)$ & DMF & 1.0 & 20 & $-c$ \\
\hline 11 & $\mathrm{BF}_{3} \cdot \mathrm{OEt}_{2}(20)$ & {$[\mathrm{bmim}] \mathrm{BF}_{4}$} & 1.0 & 20 & 17 \\
\hline 12 & $\mathrm{BF}_{3} \cdot \mathrm{OEt}_{2}(20)$ & $\mathrm{MeCN}$ & 1.0 & 0 & 54 \\
\hline 13 & $\mathrm{BF}_{3} \cdot \mathrm{OEt}_{2}(20)$ & $\mathrm{MeCN}$ & 1.0 & 50 & Trace $^{b}$ \\
\hline 14 & $\mathrm{BF}_{3} \cdot \mathrm{OEt}_{2}(20)$ & $\mathrm{MeCN}$ & 1.5 & 20 & 23 \\
\hline 15 & $\mathrm{BF}_{3} \cdot \mathrm{OEt}_{2}(20)$ & $\mathrm{MeCN}$ & 2.0 & 20 & 3 \\
\hline 16 & $\mathrm{FeCl}_{3}(10)$ & $\mathrm{MeCN}$ & 1.0 & 20 & Trace $^{b}$ \\
\hline 17 & $\mathrm{Ni}\left(\mathrm{NO}_{3}\right)_{2}(10)$ & $\mathrm{MeCN}$ & 1.0 & 20 & $-^{\mathrm{c}}$ \\
\hline
\end{tabular}

${ }^{a}$ Isolated yields are for an average of two runs. ${ }^{b}$ Determined by ${ }^{1} \mathrm{H}$ NMR spectroscopy. ${ }^{c}$ Decomposition of initial compounds was observed.

This approach to the (1H-1,2,3-triazol-1-yl)furoxan scaffold assembly encouraged us to examine the substrate scope of the reaction of aminofuroxans $\mathbf{2}$ with diazo- $\beta$-dicarbonyl compounds $\mathbf{3}$. The reaction of aminofuroxans 2a-d incorporating phenyl, methyl, ester and acetyl groups respectively proceeded successfully with 3-diazo-2,4-dioxopentane (3a), however, the highest yield of final 1,2,3-triazole was obtained for compound 1a. Among diazo compounds, 2-diazoacetoacetic ester (3b) was found to be less reactive since the yields of final products $\mathbf{1} \mathbf{b}, \mathbf{d}, \mathbf{f}$ were lower in comparison with the yields of compounds $\mathbf{1 a , c , e}$. Moreover, the 
reaction of aminofuroxan $\mathbf{2} \mathbf{d}$ comprising acetyl group at $\mathrm{C}(3)$ atom of the furoxan ring with diazo compound $\mathbf{3 b}$ did not occur. In general, the yields of ( $1 \mathrm{H}-1,2,3$-triazol-1-yl)furoxans were moderate which is explained by low basicity and low nucleophilicity of aminofuroxans due to the strong electron-withdrawing effect of the furoxan ring. ${ }^{39}$ Interestingly, the reaction of 3-amino-4-phenylfuroxan, which is more nucleophilic than the corresponding 4-amino isomer $\mathbf{2 a}$, with diazo compound $\mathbf{3 a}$ did not occur due to the decomposition of starting materials.

Table 2. Substrate scope for the reaction of aminofuroxans $\mathbf{2}$ with diazo compounds $\mathbf{3}^{\mathrm{a}}$
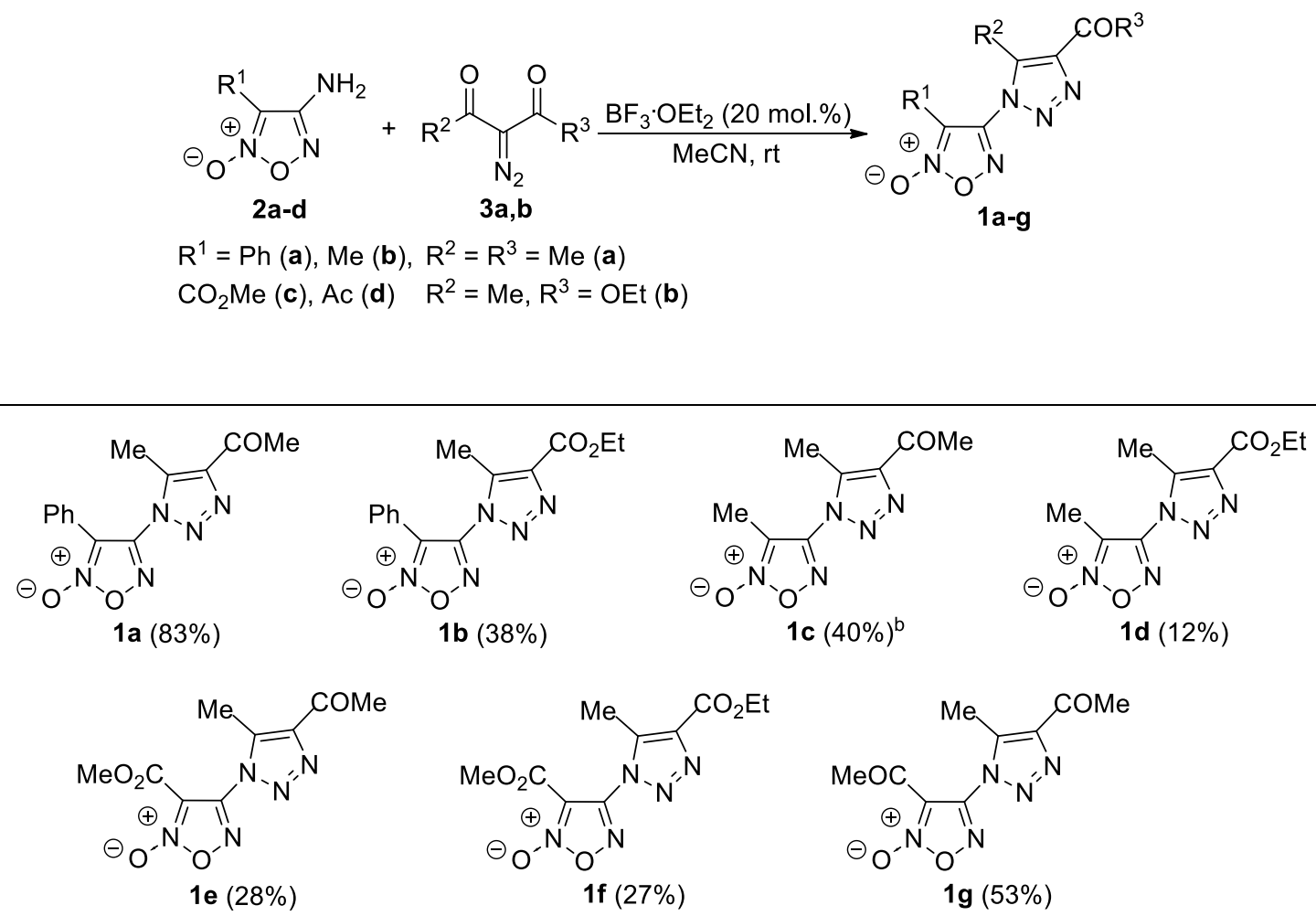

a Isolated yields are for an average of two runs. $\quad$ b 1.5 equiv. of 3a were used.

A plausible mechanism for the $\mathrm{BF}_{3} \cdot \mathrm{OEt}_{2}$-catalyzed reaction of aminofuroxans $\mathbf{2}$ with diazo compounds $\mathbf{3}$ is outlined in Scheme 1. Since aminofuroxans are of very low basicity and correspond to weak nucleophiles ${ }^{39}$ it seems that $\mathrm{BF}_{3} \cdot \mathrm{OEt}_{2}$ activates the diazo compound $\mathbf{3}$ to generate complex $\mathbf{4}$. The electrophilicity of the carbonyl group in intermediate $\mathbf{4}$ has increased enough for the condensation with aminofuroxan 2 to occur. Finally, the intramolecular cyclization in imine $\mathbf{5}$ completes the regioselective 1,2,3-triazole 1 formation incorporating $\mathrm{R}^{2}$ substituent at $\mathrm{C}(5)$ atom of the triazole ring.

All of the synthesized ( $1 H-1,2,3$-triazol-1-yl)furoxans $1 \mathrm{a}-\mathrm{g}$ were characterized by spectral and analytical methods. Finally, we confirmed the structures of the 1,2,3-triazole derivatives by a single-crystal X-ray diffraction study of the representative compound 1a (Figure 1). 

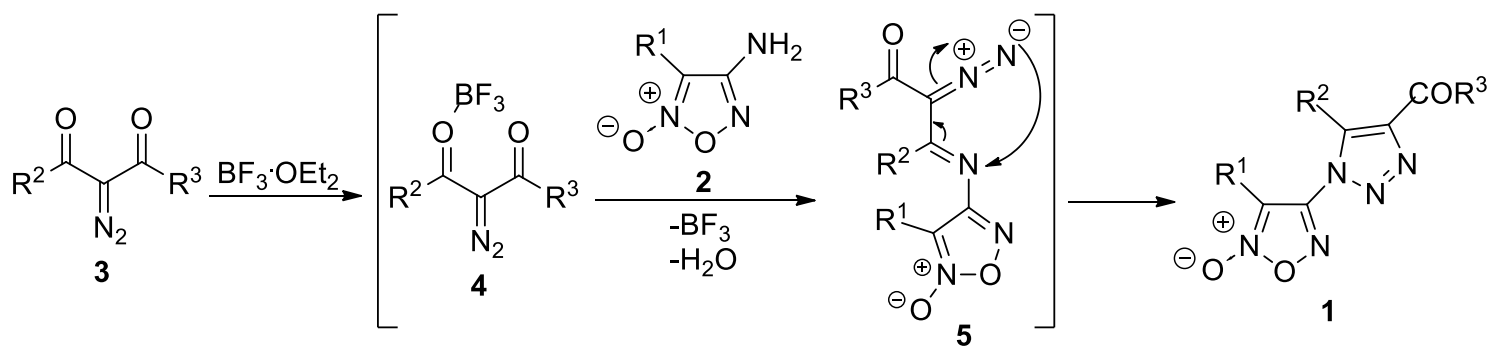

Scheme 1. Plausible mechanism for (1H-1,2,3-triazol-1-yl)furoxan (1) formation.

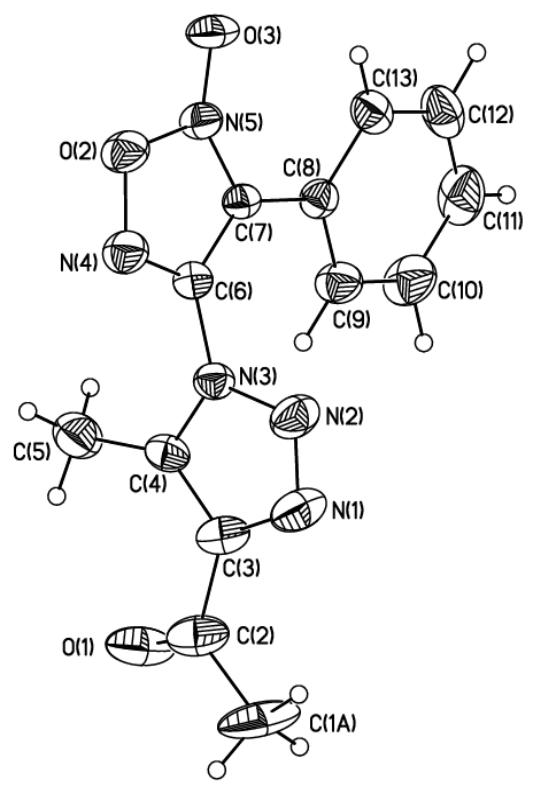

Figure 1. A general view of the 1a molecule. Non-hydrogen atoms are represented by probability ellipsoids of atomic vibrations $(p=50 \%)$.

According to X-ray data compound $\mathbf{1 a}$ is the first structurally characterized furoxan derivative with a triazole ring (Figure 1). The mutual orientation of cyclic fragments is noteworthy: the $\mathrm{N}(2) \mathrm{N}(3) \mathrm{C}(6) \mathrm{C}(7)$ torsion angle is $74.8(6)^{\circ}$, while the $\mathrm{C}(13) \mathrm{C}(8) \mathrm{C}(7) \mathrm{N}(5)$ torsion angle is $15.9(8)^{\circ}$. The corresponding $\pi$-conjugation between phenyl and furoxan rings is a known attribute of phenylfuroxans ${ }^{44}$ (the $C(7)-C(8)$ bond length is 1.461(2) $\AA$ ), its lack between two electron-withdrawing heterocycles is in line with the rather large bond length of the $C(6)-N(3)$ bond (1.401(2) $\AA$ ). The combination of conjugation effects and steric hindrance in the 1a molecule causes the formation of quite strong intermolecular stacking interactions (the $C(7) \ldots C(13)$ distance is $3.289(2) \AA$ ) together with weak C-H...O contacts (the $\mathrm{C}(9) \ldots \mathrm{O}(3)$ distance is $3.119(2) \AA$, with $\mathrm{C}-\mathrm{H}$ bond length being normalized on $1.080 \AA$ the $\mathrm{O}(3) \ldots \mathrm{H}(5 \mathrm{C})$ distance is $2.355 \AA$ ). These supramolecular forces lead to association of molecules into continuous piles (Figure 2a). An interesting "key-lock" contacts are also presented in crystal which can be described as an interaction between lone electron pair of the $N(4)$ nitrogen atom of furoxan cycle and $\pi^{*}$-orbital of triazole ring (the $C(4) \ldots N(4)$ distance is 3.223(2) $\AA$ ); these interactions bind piles into layers (Figure $2 \mathrm{~b}$ ). The 3D-crystal structure is stabilized by weak hydrogen bonds between acetyl fragment and the $\mathrm{O}(3)$ oxygen atom of the furoxan ring (with normalized $\mathrm{C}-\mathrm{H}$ bonds the $\mathrm{H}(1 \mathrm{AC}) \ldots \mathrm{O}(3)$ distance is greater than $2.51 \AA$ ). It is interesting to note that the $\mathrm{O}(1)$ oxygen atom does not participate in any 
of intermolecular contacts which may serve as an explanation of disordering of acetyl fragment on three positions (the occupation ratio is $2: 2: 1$ ).

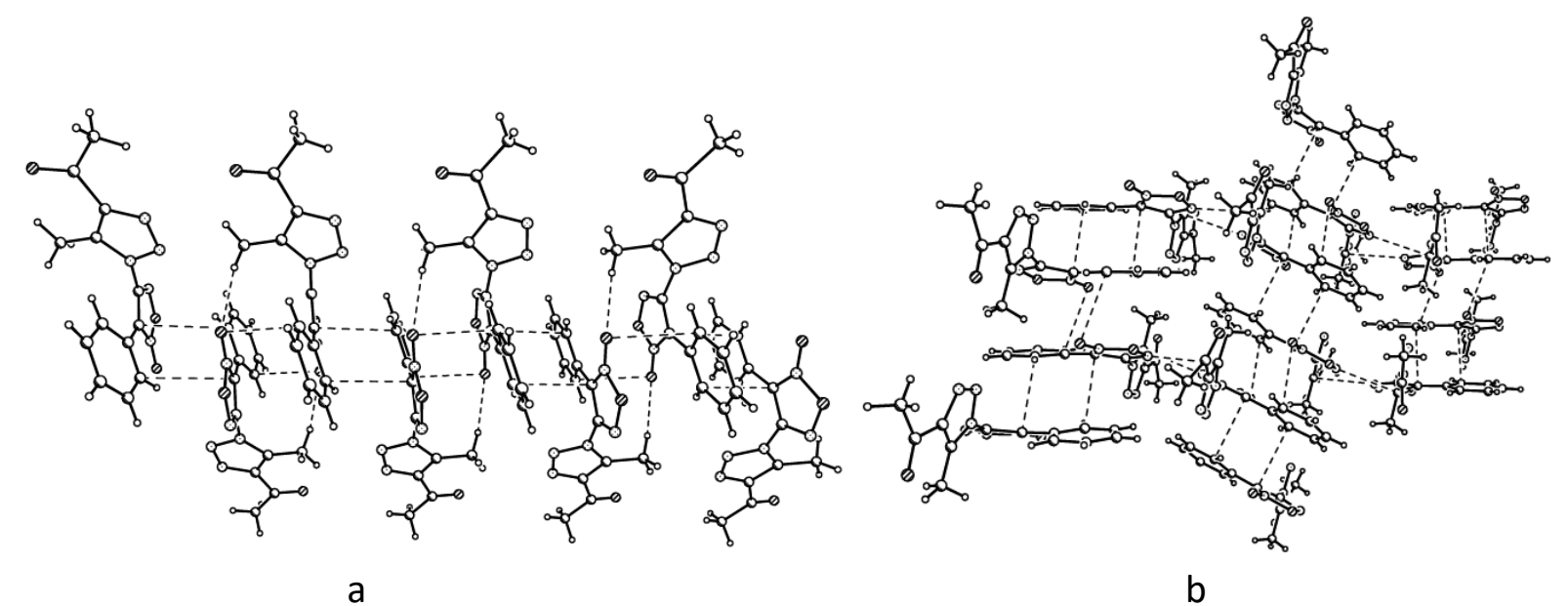

Figure 2. The fragment of piles in the crystal of 1a (a) and the fragment of a layer (b).

\section{Conclusions}

In summary, atom-economical approach to the synthesis of $\left(1 \mathrm{H}-1,2,3\right.$-triazol-1-yl)furoxans based on $\mathrm{BF}_{3} \cdot \mathrm{OEt}_{2-}$ catalyzed Wolff cyclocondensation of aminofuroxans with diazo compounds has been developed. The advantages of this method are operational simplicity, step economy and the use of readily accessible reagents. It was estimated that the reaction is quite sensitive to the nature of the substituent either at furoxan ring or in diazo derivative. Capability to participate in Wolff cyclocondensation decreases with an increase of the electron-withdrawing character of the functional groups in both substrates.

\section{Experimental Section}

General. All reactions were carried out in well-cleaned oven-dried glassware with magnetic stirring. ${ }^{1} \mathrm{H}$ and ${ }^{13} \mathrm{C}$ NMR spectra were recorded on a Bruker AM-300 (300.13 and $75.47 \mathrm{MHz}$, respectively) spectrometer and referenced to residual solvent peak. The chemical shifts are reported in ppm ( $\delta)$; multiplicities are indicated by $\mathrm{s}$ (singlet), d (doublet), $\mathrm{t}$ (triplet), qv (quartet), $\mathrm{m}$ (multiplet) and br (broad). Coupling constants, $\mathrm{J}$, are reported in Hertz. The IR spectra were recorded on a Bruker "Alpha" spectrometer in the range $400-4000 \mathrm{~cm}^{-1}$ (resolution $2 \mathrm{~cm}^{-1}$ ). Elemental analyses were performed by the CHN Analyzer Perkin-Elmer 2400. The melting points were determined on "Stuart SMP20" melting point apparatus and are uncorrected. Analytical thin-layer chromatography (TLC) was carried out on Merck 25 TLC silica gel $60 \mathrm{~F}_{254}$ aluminum sheets. The visualization of the TLC plates was accomplished with a UV light. Column chromatography was performed on silica gel $60 \mathrm{~A}$ (0.060-0.200 mm, Acros Organics). All solvents were purified and dried using standard methods prior to use. 4Amino-3-phenylfuroxan $\mathbf{2 a},{ }^{45}$ 4-amino-3-methylfuroxan $\mathbf{2 b},{ }^{46}$ 4-amino-3-(methoxycarbonyl)furoxan $\mathbf{2 c}{ }^{47}$ 3acetyl-4-aminofuroxan $\mathbf{2} \mathbf{d}^{48}$ and diazo compounds $\mathbf{3} \mathbf{a}, \mathbf{b}^{41}$ were synthesized according literature. All other reagents were purchased from Acros Organics and used without further purification.

Crystallographic data. Crystals of $1 \mathrm{a}\left(\mathrm{C}_{13} \mathrm{H}_{11} \mathrm{~N}_{5} \mathrm{O}_{3}, M=285.27\right)$ are monoclinic, space group P2/n, at $120 \mathrm{~K}: a=$ $12.284(2), b=6.9526(14), c=16.078(4) \AA, \beta=100.501(4)^{\circ}, V=1350.1(5) \AA^{3}, d_{c a l c}=1.403 \mathrm{~g} \cdot \mathrm{cm}^{-3}, \mu=1.04$ 
$\mathrm{mm}^{-1}, \mathrm{~F}(000)=592$. Intensities of 8022 reflections were measured with a Bruker APEX II CCD diffractometer $\left[\lambda(\mathrm{MoK} \alpha)=0.71072 \AA, \omega\right.$-scans, $\left.2 \theta<73^{\circ}\right]$ and 5525 independent reflections $\left[R_{\text {int }}=0.0242\right]$ were used in further refinement. The structure was solved by direct method and refined by the full-matrix least-squares technique against $F^{2}$ in the isotropic-anisotropic approximation. The hydrogen atoms $\mathrm{H}(\mathrm{C})$ positions were calculated. All hydrogen atoms were refined in the isotropic approximation within the riding model. For 1a, the refinement converged to $w R 2=0.1974$ and GOF $=1.004$ for all independent reflections $(R 1=0.0619$ was calculated against $F$ for 2902 observed reflections with $I>2 \sigma(I))$. The disorder of the $O(1)$ and $C(1 A)$ atoms was modeled with superposition of three places due to the lowest residual density peaks observed for such consideration. The final refinement was done using restraints on the bond lengths (with maximum shift parameters up to 0.01 Ang.) and constraints on the anisotropic displacement parameters from different parts. All calculations were performed using SHELX 2014. ${ }^{49,50}$ CCDC 1528040 contain the supplementary crystallographic data for 1 . These data can be obtained free of charge via http://www.ccdc.cam.ac.uk/conts/retrieving.html, or from the CCDC, 12 Union Road, Cambridge, CB21EZ, UK; or deposit@ccdc.cam.ac.uk.

General procedure for the synthesis of (1H-1,2,3-triazol-1-yl)furoxans 1 . The corresponding aminofuroxan 2 $(1 \mathrm{mmol})$ was added in one portion to a magnetically stirred solution of diazo compound 3 ( $1 \mathrm{mmol}$ ) in MeCN $(2 \mathrm{~mL})$ at room temperature. Then $\mathrm{BF}_{3} \cdot \mathrm{Et}_{2} \mathrm{O}(5 \mu \mathrm{L}, 0.2 \mathrm{mmol})$ was added. The reaction mixture was stirred until complete consumption of the initial aminofuroxan 2 (TLC monitoring, eluent $\mathrm{CHCl}_{3}$ : EtOAc = 15:1). Then the solvent was evaporated in vacuo and the residue was purified by column chromatography on $\mathrm{SiO}_{2}(\mathrm{eluent}$ $\mathrm{CHCl}_{3}:$ EtOAC $\left.=15: 1\right)$.

4-(4-Acetyl-5-methyl-1H-1,2,3-triazol-1-yl)-3-phenylfuroxan (1a). Yellow needles; yield $237 \mathrm{mg}$ (83\%); m.p.: 108.0-109.5 ${ }^{\circ} \mathrm{C}(\mathrm{MeCN}) ; \mathrm{R}_{f} 0.54\left(\mathrm{CHCl}_{3}: \mathrm{EtOAC}=15: 1\right)$; IR $\left(\mathrm{KBr}, \mathrm{v}_{\max }, \mathrm{cm}^{-1}\right): 2963,2923,2854,1689,1614,1546$, 1477, 1448, 1367, 1264, 967; ${ }^{1} \mathrm{H}$ NMR $\left(300 \mathrm{MHz}_{\mathrm{CDCl}}\right.$ ) $\delta_{\mathrm{H}}: 2.64\left(\mathrm{~s}, 3 \mathrm{H}, \mathrm{CH}_{3}\right), 2.79\left(\mathrm{~s}, 3 \mathrm{H}, \mathrm{COCH}_{3}\right), 7.41-7.51(\mathrm{~m}$, $5 \mathrm{H}, \mathrm{Ph}) ;{ }^{13} \mathrm{C}$ NMR $\left(75.5 \mathrm{MHz}, \mathrm{CDCl}_{3}\right) \delta_{\mathrm{C}}$ : 9.4, 28.1, 110.9, 120.1, 127.2, 129.5, 131.6, 140.1, 143.4, 148.0, 193.5; Calcd for $\mathrm{C}_{13} \mathrm{H}_{11} \mathrm{~N}_{5} \mathrm{O}_{3}$ : C, 57.74; $\mathrm{H}, 3.89 ; \mathrm{N}, 24.55$; Found: $\mathrm{C}, 57.66 ; \mathrm{H}, 3.97 ; \mathrm{N}, 24.67 \%$.

4-[4-(Ethoxycarbonyl)-5-methyl-1H-1,2,3-triazol-1-yl]-3-phenylfuroxan (1b). Yellow prisms; yield $120 \mathrm{mg}$ (38\%); m.p.: 121.5-122.2 ${ }^{\circ} \mathrm{C}(\mathrm{MeCN}) ; \mathrm{R}_{f} 0.55\left(\mathrm{CHCl}_{3}\right.$ : EtOAc = 15:1); IR (KBr, $\left.\mathrm{v}_{\max } \mathrm{cm}^{-1}\right)$ : 2989, 1736, 1605, 1448, $1263,1215,1179,1107,776 ;{ }^{1} \mathrm{H}$ NMR $\left(300 \mathrm{MHz}, \mathrm{CDCl}_{3}\right) \delta_{\mathrm{H}}: 1.24\left(\mathrm{t}, 3 \mathrm{H}, \mathrm{COCH}_{2} \mathrm{C}_{3},{ }^{3} \mathrm{~J} 7.1 \mathrm{~Hz}\right), 2.62\left(\mathrm{~s}, 3 \mathrm{H}, \mathrm{CH}_{3}\right)$, 4.47 (q, $\left.2 \mathrm{H}, \mathrm{COCH}_{2} \mathrm{CH}_{3},{ }^{3} \mathrm{~J} 7.1 \mathrm{~Hz}\right), 7.35-7.49(\mathrm{~m}, 5 \mathrm{H}, \mathrm{Ph}) ;{ }^{13} \mathrm{C} \mathrm{NMR}\left(75.5 \mathrm{MHz}, \mathrm{CDCl}_{3}\right) \delta_{\mathrm{c}}: 9.4,14.3,61.7,111.0$, $120.1,127.1,129.5,131.7,137.2,141.5,148.1,160.8$; HRMS (ESI) $m / z$ calcd for $\mathrm{C}_{14} \mathrm{H}_{14} \mathrm{~N}_{5} \mathrm{O}_{4}(\mathrm{M}+\mathrm{H})^{+}$: 316.1040, found 316.1030.

4-(4-Acetyl-5-methyl-1H-1,2,3-triazol-1-yl)-3-methylfuroxan (1c). Yellow prisms; yield $89 \mathrm{mg}$ (40\%); m.p.: 87.1-88.5 ${ }^{\circ} \mathrm{C}(\mathrm{MeCN}) ; \mathrm{R}_{f} 0.63\left(\mathrm{CHCl}_{3}:\right.$ EtOAC = 15:1); IR ( KBr, $\left.\mathrm{v}_{\max } \mathrm{cm}^{-1}\right): 2964,2920,1692,1621,1546,1487$, 1372, 1301; ${ }^{1} \mathrm{H}$ NMR (300 MHz, CDCl 3 ) $\delta_{\mathrm{H}}: 2.49$ (s, 3H, $\mathrm{CH}_{3}$ furoxan), 2.75 (s, 3H, $\mathrm{CH}_{3}$ triazole), 2.88 (s, 3H, $\left.\mathrm{COCH}_{3}\right) ;{ }^{13} \mathrm{C} \mathrm{NMR}\left(75.5 \mathrm{MHz}, \mathrm{CDCl}_{3}\right) \delta_{\mathrm{c}}: 9.4,10.3,28.2,108.8,139.4,143.6,150.6,193.5 ; \mathrm{HRMS}$ (ESI) m/z: calcd for $\mathrm{C}_{8} \mathrm{H}_{10} \mathrm{~N}_{5} \mathrm{O}_{3}(\mathrm{M}+\mathrm{H})^{+} 224.0778$, found 224.0772 .

4-[4-(Ethoxycarbonyl)-5-methyl-1H-1,2,3-triazol-1-yl]-3-methylfuroxan (1d). Yellow oil; yield $30 \mathrm{mg}(12 \%) ; \mathrm{R}_{f}$ $0.59\left(\mathrm{CHCl}_{3}:\right.$ EtOAC = 15:1); IR (thin layer, $\left.v_{\max } \mathrm{cm}^{-1}\right): 2984,2935,2857,1724,1630,1554,1494,1416,1342$, 1236, 1203, 1114, 1032, 848; ${ }^{1} \mathrm{H}$ NMR $\left(300 \mathrm{MHz}_{\mathrm{CDCl}}\right) \delta_{\mathrm{H}}: 1.46\left(\mathrm{t}, 3 \mathrm{H}, \mathrm{COCH}_{2} \mathrm{CH}_{3},{ }^{3} \mathrm{~J} 7.1 \mathrm{~Hz}\right), 2.48\left(\mathrm{~s}, 3 \mathrm{H}, \mathrm{CH}_{3}\right.$ furoxan), 2.91 (s, $3 \mathrm{H}, \mathrm{CH}_{3}$ triazole), $4.49\left(\mathrm{q}, 2 \mathrm{H}, \mathrm{COCH}_{2} \mathrm{CH}_{3},{ }^{3} \mathrm{~J} 7.1 \mathrm{~Hz}\right) ;{ }^{13} \mathrm{C} \mathrm{NMR}\left(75.5 \mathrm{MHz}, \mathrm{CDCl}_{3}\right) \delta_{\mathrm{c}}: 9.4,10.4$, $14.3,61.7,108.8,137.5,140.7,150.6,160.8$. Calcd for $\mathrm{C}_{9} \mathrm{H}_{11} \mathrm{~N}_{5} \mathrm{O}_{4}$ (\%): C, 42.69; $\mathrm{H}, 4.38 ; \mathrm{N}, 27.66$; Found: C, $42.81 ; H, 4.30 ; N, 27.53 \%$.

4-(4-Acetyl-5-methyl-1H-1,2,3-triazol-1-yl)-3-(methoxycarbonyl)furoxan (1e). Yellow oil; yield $75 \mathrm{mg}(28 \%) ; \mathrm{R}_{f}$ $0.51\left(\mathrm{CHCl}_{3}:\right.$ EtOAC = 15:1); IR (KBr, $\left.v_{\max }, \mathrm{cm}^{-1}\right): 2973,2926,2854,1744,1692,1630,1547,1492,1435,1318$, 1216, 1183, 1029, 947, 782; ${ }^{1} \mathrm{H}$ NMR $\left(300 \mathrm{MHz}, \mathrm{CDCl}_{3}\right) \delta_{\mathrm{H}}: 2.71\left(\mathrm{~s}, 3 \mathrm{H}, \mathrm{CH}_{3}\right.$ triazole), $2.78\left(\mathrm{~s}, 3 \mathrm{H}, \mathrm{COCH}_{3}\right), 3.90$ 
(s, 3H, $\left.\mathrm{COOCH}_{3}\right) ;{ }^{13} \mathrm{C}$ NMR (75.5 MHz, CDCl 3 ) $\delta_{\mathrm{c}}: 9.5,28.1,54.1,104.1,140.3,143.1,146.6,154.8,193.5 ;$ Calcd for $\mathrm{C}_{9} \mathrm{H}_{9} \mathrm{~N}_{5} \mathrm{O}_{5}$ : C, 40.46; $\mathrm{H}, 3.40 ; \mathrm{N}, 26.21$; Found: $\mathrm{C}, 40.33 ; \mathrm{H}, 3.51 ; \mathrm{N}, 26.08 \%$.

4-(4-(Ethoxycarbonyl)-5-methyl-1H-1,2,3-triazol-1-yl)-3-(methoxycarbonyl)furoxan (1f). Yellow oil; yield 80 $\mathrm{mg}(27 \%) ; \mathrm{R}_{f} 0.55\left(\mathrm{CHCl}_{3}:\right.$ EtOAc $\left.=15: 1\right) ;{ }^{1} \mathrm{H} \mathrm{NMR}\left(300 \mathrm{MHz}, \mathrm{CDCl}_{3}\right) \delta_{\mathrm{H}}: 1.43\left(\mathrm{t}, 3 \mathrm{H}, \mathrm{COCH}_{2} \mathrm{CH}_{3},{ }^{3} \mathrm{~J} 7.1 \mathrm{~Hz}\right), 2.71$ $\left(\mathrm{s}, 3 \mathrm{H}, \mathrm{CH}_{3}\right), 3.88\left(\mathrm{~s}, 3 \mathrm{H}, \mathrm{COOCH}_{3}\right), 4.49$ (q, 2H, OC$\left.{ }_{2} \mathrm{CH}_{3},{ }^{3} \mathrm{~J} 7.1 \mathrm{~Hz}\right) ;{ }^{13} \mathrm{C} \mathrm{NMR}\left(75.5 \mathrm{MHz}, \mathrm{CDCl}_{3}\right) \delta_{\mathrm{c}}: 8.2,9.1$, 48.9, 56.4, 111.3, 136.2, 141.3, 149.5, 154.2, 155.5; Calcd for $\mathrm{C}_{10} \mathrm{H}_{11} \mathrm{~N}_{5} \mathrm{O}_{6}$ : C, 40.41; $\mathrm{H}, 3.73$; $\mathrm{N}, 23.56$; Found: $\mathrm{C}$, 40.29; H, 3.85; N, $23.69 \%$.

3-Acetyl-4-(4-acetyl-5-methyl-1H-1,2,3-triazol-1-yl)furoxan (1g). Yellow oil; yield $133 \mathrm{mg}(53 \%) ; \mathrm{R}_{f} 0.60$ $\left(\mathrm{CHCl}_{3}:\right.$ EtOAC = 15:1); IR (thin layer, $\left.v_{\max }, \mathrm{cm}^{-1}\right): 2925,2851,1688,1618,1545,1372,1016,954,620 ;{ }^{1} \mathrm{H} \mathrm{NMR}$ (300 MHz, CDCl ${ }_{3}$ ) $\delta_{\mathrm{H}}: 2.59\left(\mathrm{~s}, 3 \mathrm{H}, \mathrm{CH}_{3}\right.$ triazole), 2.61 (s, 3H, $\mathrm{COCH}_{3}$ furoxan), 2.71 (s, 3H, $\mathrm{COCH}_{3}$ triazole); ${ }^{13} \mathrm{C}$ NMR (75.5 MHz, $\mathrm{CDCl}_{3}$ ) $\delta_{c}: 9.2,27.8,28.5,109.2,140.2,142.9,146.5,184.0,193.4$; Calcd for $\mathrm{C}_{9} \mathrm{H}_{9} \mathrm{~N}_{5} \mathrm{O}_{4}: \mathrm{C}_{\text {, }}$ 43.03; H, 3.61; N, 27.88; Found: C, 42.94; H, 3.79; N, $27.76 \%$.

\section{Acknowledgements}

Support from the Russian Foundation for Basic Research (Projects 16-33-00564 and 16-29-01042) and the Russian President's Council for Grants (Project MK-1302.2017.3) is greatly acknowledged.

\section{References}

1. Ananikov, V. P.; Khokhlova, E. A.; Egorov, M. P.; Sakharov, A. M.; Zlotin, S. G.; Kucherov, A. V.; Kustov, L. M.; Gening, M. L.; Nifantiev, N. E. Mendeleev Commun. 2015, 25, 75-82.

https://doi.org/10.1016/i.mencom.2015.03.001

2. Ananikov, V. P.; Galkin, K. I.; Egorov, M. P.; Sakharov, A. M.; Zlotin, S. G.; Redina, E. A.; Isaeva, V. I.;

Kustov, L. M.; Gening, M. L.; Nifantiev, N. E. Mendeleev Commun. 2016, 26, 365-374.

https://doi.org/10.1016/j.mencom.2016.09.001

3. Makhova, N. N.; Kulikov, A. S. Russ. Chem. Rev. 2013, 82, 1007-1033.

https://doi.org/10.1070/RC2013v082n11ABEH004369

4. Fershtat, L. L.; Makhova, N. N. Russ. Chem. Rev. 2016, 85, 1097-1145.

https://doi.org/10.1070/RCR4619

5. He, C.; Shreeve, J. M. Angew. Chem., Int. Ed. 2016, 128, 782-785.

https://doi.org/10.1002/ange.201509209

6. Tang, Y.; He, C.; Mitchell, L. A.; Parrish, D. A.; Shreeve, J. M. Chem. Eur. J. 2016, 22, 11846-11853. https://doi.org/10.1002/chem.201602171

7. Chizhov, A. O.; Makhova, N. N.; Kuchurov, I. V.; Sheremetev, A. B.; Zlotin, S. G. Mendeleev Commun. 2014, 24, 165-166.

https://doi.org/10.1016/i.mencom.2014.04.014

8. Fischer, D.; Klapötke, T. M.; Stierstorfer, J. Eur. J. Inorg. Chem. 2014, 5808-5811. https://doi.org/10.1002/ejic.201402960

9. Klapötke, T. M.; Witkowski, T. G. Propellants Explos. Pyrotech. 2015, 40, 366-373. https://doi.org/10.1002/prep.201400294

10. Fershtat, L. L.; Ovchinnikov, I. V.; Makhova, N. N. Tetrahedron Lett. 2014, 55, 2398-2400. https://doi.org/10.1016/i.tetlet.2014.02.112 
11. Fershtat, L. L.; Epishina, M. A.; Kulikov, A. S.; Ovchinnikov, I. V.; Ananyev, I. V.; Makhova, N. N.

Tetrahedron 2015, 71, 6764-6775.

https://doi.org/10.1016/i.tet.2015.07.034

12. Fershtat, L. L.; Larin, A. A.; Epishina, M.A.; Kulikov, A.S.; Ovchinnikov, I. V.; Ananyev, I. V; Makhova, N. N.

Tetrahedron Lett. 2016, 57, 4268-4272.

https://doi.org/10.1016/i.tetlet.2016.08.011

13. Cena, C.; Bertinaria, M.; Boschi, D.; Giorgis, M.; Gasco, A. Arkivoc 2006, (vii), 301-309.

http://dx.doi.org/10.3998/ark.5550190.0007.722

14. Paton, R. M. In Comprehensive Heterocyclic Chemistry II; Katritzky, A. R.; Rees, C. W.; Scriven, E. F. V. Eds.; Elsevier: Oxford, 1996; Vol. 4, pp 229-265.

https://doi.org/10.1016/B978-008096518-5.00083-6

15. Nikonov, G. N.; Bobrov, S. In Comprehensive Heterocyclic Chemistry III; Katritzky, A. R.; Ramsden, C. A.; Scriven, E. F. V.; Taylor, R. J. K. Eds.; Elsevier: Amsterdam, 2008; Vol. 5, pp 316-393.

16. Borretto, E.; Lazzarato, L.; Spallotta, F.; Cencioni, C.; D'Alessandra, Y.; Gaetano, C.; Fruttero, R.; Gasco, A. ACS Med. Chem. Lett. 2013, 4, 994-999.

https://doi.org/10.1021/ml400289e

17. Guglielmo, S.; Cortese, D.; Vottero, F.; Rolando, B.; Kommer, V. P.; Williams, D. L.; Fruttero, R.; Gasco, A. Eur. J. Med. Chem. 2014, 84, 135-145. https://doi.org/10.1016/j.ejmech.2014.07.007

18. Fruttero, R.; Bertinaria, M.; Orjuela-Sanchez, P.; Marini, E.; Guglielmo, S.; Hofer A.; Chaves Martins, Y.; Zanini, G.; Frangos, J. A.; Gasco, A.; Carvalho, L. J. Med. Chem. 2015, 58, 7895-7899.

https://doi.org/10.1021/acs.jmedchem.5b01036

19. Kumar, S. N.; Kumar, C. N. S. S. P.; Anudeep, S. R. V.; Sharma, K. K.; Rao, V. J.; Babu, N. J. Arkivoc 2016, (v), 32-49.

http://dx.doi.org/10.3998/ark.5550190.p009.669

20. Fershtat, L. L.; Epishina, M. A.; Kulikov, A. S.; Struchkova, M. I.; Makhova, N. N. Chem. Heterocycl. Compd. 2015, 51, 176-186.

https://doi.org/10.1007/s10593-015-1678-5

21. Fershtat, L. L.; Epishina, M. A.; Kulikov, A. S.; Makhova, N. N. Mendeleev Commun. 2015, 25, 36-38. https://doi.org/10.1016/j.mencom.2015.01.013

22. Fershtat, L. L.; Ashirbaev, S. S.; Kulikov, A. S.; Kachala, V. V.; Makhova, N. N. Mendeleev Commun. 2015, 25, 257-259.

https://doi.org/10.1016/j.mencom.2015.07.007

23. Fershtat, L. L.; Struchkova, M. I.; Goloveshkin, A. S.; Bushmarinov, I. S.; Makhova, N. N. Heteroat. Chem. 2014, 25, 226-237.

https://doi.org/10.1002/hc.21166

24. Fershtat, L. L.; Ananyev, I. V.; Makhova, N. N. RSC Adv. 2015, 5, 47248-47260. https://doi.org/10.1039/C5RA07295F

25. Fershtat, L. L.; Epishina, M. A.; Ovchinnikov, I. V.; Makhova, N. N. Chem. Heterocycl. Compd. 2015, 51, 754-759.

https://doi.org/10.1007/s10593-015-1771-9

26. Zlotin, S. G.; Churakov, A. M.; Luk'yanov, O. A.; Makhova, N. N.; Sukhorukov, A. Yu.; Tartakovsky, V. A. Mendeleev Commun. 2015, 25, 399-409.

https://doi.org/10.1016/j.mencom.2015.11.001 
27. Fershtat, L. L.; Larin, A. A.; Epishina, M. A.; Ovchinnikov, I. V.; Ananyev, I. V.; Makhova, N. N. RSC Adv. 2016, 6, 31526-31539.

https://doi.org/10.1039/C6RA05110C

28. Fershtat, L. L.; Epishina, M. A.; Ovchinnikov, I. V.; Struchkova, M. I.; Romanova, A. A.; Ananyev, I. V.; Makhova, N. N. Tetrahedron Lett., 2016, 57, 5685-5689.

https://doi.org/10.1016/i.tetlet.2016.11.023

29. Dehne, H. In Methoden der Organischen Chemie (Houben-Weyl); Schaumann, E. Ed.; Thieme: Stuttgart, 1994; Vol. E8d, p 305-405.

30. Alvarez, R.; Velazquez, S.; San-Felix, A.; Aquaro, S.; De Clercq, E.; Perno, C. F.; Karlsson, A.; Balzarini, J.; Camarasa, M. J. J. Med. Chem. 1994, 37, 4185-4194.

https://doi.org/10.1021/jm00050a015

31. Genin, M. J.; Allwine, D. A.; Anderson, D. J.; Barbachyn, M. R.; Emmert, D. E.; Garmon, A.; Graber, D. R.; Grega, K. C.; Hester, J. B.;Hutchinson, D. K.; Morris, J.; Reischer, R. J.; Ford, C. W.; Zurenko, G. E.; Hamel, J. C.; Schaadt, R. D.; Stapert, D.; Yagi, H. J. Med. Chem. 2000, 43, 953-970. https://doi.org/10.1021/im990373e

32. Kume, M.; Kubota, T.; Kimura, Y.; Nakashimizu, H.; Motokawa, K.; Nakano, M. J. Antibiot. 1993, 46, 177192.

https://doi.org/10.7164/antibiotics.46.177

33. Dowsett, M.; Harper-Wynne, C.; Boeddinghaus, I.; Salter, J.; Hills, M.; Dixon, M.; Ebbs, S.; Gui, G.; Sacks, N.; Smith, I. Cancer Res. 2001, 61, 8452-8458.

34. Fan, W.-Q.; Katritzky, A. R. In Comprehensive Heterocyclic Chemistry II; Katritzky, A. R.; Rees, C. W.; Scriven, E. F. V. Eds.; Elsevier: Oxford, 1996; Vol. 4, pp 1-126.

https://doi.org/10.1016/B978-008096518-5.00079-4

35. Rachwal, S; Katritzky, A. R. In Comprehensive Heterocyclic Chemistry III; Katritzky, A. R.; Ramsden, C. A.; Scriven, E. F. V.; Taylor, R. J. K. Eds.; Elsevier: Amsterdam, 2008; Vol. 5, pp 1-158. https://doi.org/10.1016/B978-008044992-0.00501-0

36. Semakin, A. N.; Agababyan, D. P.; Kim, S.; Lee, S.; Sukhorukov, A. Yu.; Fedina, K. G.; Oh, J.; loffe, S. L. Tetrahedron Lett. 2015, 56, 6335-6339. https://doi.org/10.1016/i.tetlet.2015.09.106

37. Batog, L. V.; Konstantinova, L. S.; Rozhkov, V. Yu.; Strelenko, Yu. A.; Lebedev, O. V.; Khmel'nitskii, L. I. Chem. Heterocycl. Compd. 2000, 36, 91-100.

https://doi.org/10.1007/BF02256852

38. Seregin, I. V.; Batog, L. V.; Makhova, N. N. Mendeleev Commun. 2002, 12, 83-84. https://doi.org/10.1070/MC2002v012n03ABEH001590

39. Defilippi, A.; Sorba, G.; Calvino, R.; Garrone, A.; Gasco, A.; Orsetti, M. Arch. Pharm. 1988, 321, 77-80. https://doi.org/10.1002/ardp.19883210207

40. Wolff, L. Justus Liebigs Ann. Chem., 1902, 325, 129-195. https://doi.org/10.1002/ilac.19023250202

41. Wolff, L. Justus Liebigs Ann. Chem., 1912, 394, 23-59. https://doi.org/10.1002/jlac.19123940104

42. Tome, A. C. In Science of Synthesis; Storr, R. C.; Gilchrist, T. L. Eds.; Thieme: Stuttgart, 2004; Vol. 13, pp. 415-601.

43. Krivopalov, V. P.; Shkurko, O. P. Russ. Chem. Rev. 2005, 74, 339-379.

https://doi.org/10.1070/RC2005v074n04ABEH000893 
44. Taylor, R.; Allen, F. H. Statistical and Numerical Methods of Data Analysis / Structure Correlation; VCH: Weinheim, 1994; Cambridge Structural Database, release 2015.

45. Gagneux, A. R.; Meier, R. Helv. Chim. Acta 1970, 53, 1883-1892. https://doi.org/10.1002/hlca.19700530738

46. Ovchinnikov, I. V.; Blinnikov, A. N.; Makhova, N. N.; Khmel'nitskii, L. I. Mendeleev Commun. 1995, 5, 5860. https://doi.org/10.1070/MC1995v005n02ABEH000456

47. Kulikov, A. S.; Ovchinnikov, I. V.; Molotov, S. I.; Makhova, N. N. Russ. Chem. Bull., Int. Ed. 2003, 52, 18221828.

https://doi.org/10.1023/A:1026073108494

48. Makhova, N. N.; Blinnikov, A. N.; Khmel'nitskii, L. I. Mendeleev Commun. 1995, 5, 56-58. https://doi.org/10.1070/MC1995v005n02ABEH000455

49. Sheldrick, G. M. Acta Cryst. Sect. C, 2015, 71, 3-8. https://doi.org/10.1107/S2053229614024218

50. Sheldrick, G. M. Acta. Cryst. Sect. A, 2008, 64, 112-122. https://doi.org/10.1107/S0108767307043930 